\title{
Youth in Late Communism: Post-transitional Life Writing and Autobio- graphical Representations
}

\author{
Simona Mitroiu ${ }^{1}$
}

Recibido: 15 de junio de 2020 / Aceptado: 11 de julio 2020

\begin{abstract}
The paper discusses the Romanian youth's memories of the late communism. The posttransitional autobiographical texts were chosen as a main research corpus based on the temporal distance and on the revealed surpassing of the trauma memory discourse. Following the main representations and structural topics, the analyses indicate the narrativization of generational memories and representations, including the main lines of generational conflicts. The analyses also reveal a complex narrative of the past, involving the transition to youth years and specific data of the life conditions and challenges during late communism. A significant connection between nostalgia and communist memorabilia was identified. The active engagement in obtaining different commodities indicates the complex connection between nostalgia and communist memorabilia.
\end{abstract}

Keywords: youth; late communism; Romania; discourse of memory; communist memorabilia.

\section{[es] La juventud en el comunismo tardío: representación autobiográfica y escritura de vida pos-transicional}

Resumen. El texto discute las memorias de la juventud rumana durante el comunismo tardío. Los textos autobiográficos postransicionales fueron elegidos como un corpus de investigación principal basado en la distancia temporal y en la superación revelada del discurso de memoria del trauma. Siguiendo las principales representaciones y temas estructurales, los análisis indican la narrativización de los recuerdos y representaciones generacionales, incluidas las líneas principales de conflictos generacionales. Los análisis también revelan una narrativa compleja del pasado, que involucra la transición a la juventud y datos específicos de las condiciones de vida y los desafíos presentados durante el comunismo tardío. Se identificó una conexión significativa entre la nostalgia y los recuerdos comunistas. La participación activa en la obtención de diferentes productos indica la compleja conexión entre la nostalgia y el recuerdo de la época comunista.

Palabras clave: juventud; comunismo tardío; Rumania; discurso de la memoria; recuerdos comunistas.

Sumario. 1. Introduction 2. Discourses of memory and everyday life research 3. Late communism and generational discourse 4. Youth in the late communism 5. Post-transitional autobiographical literature 6. Youth memories: narrativization and self-referential writings 7. Conclusion.

Cómo citar: Mitroiu, S. (2020). Youth in late Communism: post-transitional Life Writing and Autobiographical Representations. Cuadernos de Historia Contemporánea, Vol. 42: 97-115.

1 Institute of Interdisciplinary Research, Alexandru Ioan Cuza University of Iași, Romania simona.mitroiu@uaic.ro 


\section{Introduction}

Researchers of everyday life highlight the average individuals' agency in the former communist Eastern European states, challenging the previous narratives that insisted upon the absolute power of the political dictatorial regimes and the elites' unique capacity to challenge the regime policies. Furthermore, the everyday life in socialism was largely explored following two main directions: the consumption during the soviet regime and the nostalgic approach of the past. In the second part of this paper I am using this framework of agency, consumption and nostalgia in reading different autobiographical narratives. My research is grounded on the intersection between the everyday life history (Alltagsgeschichte) research and studies on life writing. In her introduction to Experiments in Life-Writing, Julia Novak writes that "the modes of writing about historical lives have diversified enormously, and continue to do so"2. Zachary Leader extends the area of life writing - a loose umbrella term - using the concept to include "a range of writings about lives or parts of lives, or which provide materials out of which lives or parts of lives are composed"3. The writings encompassed in Leader's presentation vary from memoir, autobiography, biography, diaries, autobiographical fiction, to letters, writs, wills, written depositions, court proceedings, lyric poems and digital forms. For the purpose of this paper, I am focusing on the life writing in direct relation to "autobiographical discourse", more precisely to the "self-referential writing".

My aim is to discuss the memory of the late communism in Romania in the autobiographical texts written after the transitional years and to elaborate further on the directions indicated above. The consumption (in terms of presence and absence of the daily goods, daily practices, and instruments) is directly related to the social context under analysis. On the other hand, the nostalgic approach is inherently associated with late communism and with a generational approach. The post-transitional literature was chosen as a main research corpus based both on its temporal distance and the explicit surpassing of the trauma memory discourse, alongside its extended and polyphonic approach of the communist past memories and practices. A second type of transition is also followed, a chronological and formative one, namely the transition from childhood years to early adulthood. The material to be analyzed was selected based on chronological and topical criteria in order to indicate the autobiographically created portrait of the Romanian youth in the late communism. Examining the youth's memories in their autobiographical writings, special attention is paid to the narrativization of generational memories and representations. While highlighting the main representations and structural topics, I am also indicating the lines of generational conflicts and continuities. Different volumes were selected based on their life writing approach and the inclusion of youth memories. Some of them focus on the everyday life in communism - such is the case of Dan Lungu and Amelia Gheorghiţă's edited volume Books, Movies, Music and other Distractions

2 Novak, Julia: "Experiments in Life-Writing: Introduction" in Lucia Boldrini, Julia Novak (eds): Experiments In Life-Writing. Intersections of Auto/Biography and Fiction, New York, Palgrave Macmillan, 2017, pp. 1-36, here p. 1.

3 Leader, Zachary: "Introduction" in Zachary Leader (ed.): On Life-Writing, Oxford, Oxford University Press, 2015, pp. 1-6, here p. 1.

4 Smith, Sidonie, Watson, Julia: Reading Autobiography: A Guide for Interpreting Life Narratives, Minneapolis and London, University of Minnesota Press, 2001, pp. 3-4. 
under Communism - others indirectly include through their contributors' memories references to the youth's lives in communism, such as the volumes published between 2009 and 2013 by the ART publishing house in the series My first. Discussing the narrativization of generational memories and representations, I am also focusing on the agency component, on its forms and presence in autobiographical writings.

\section{Discourses of memory and everyday life research}

The communist regime dominated the Romanian society for more than four decades, reshaping the public and private life and affecting the individual and collective narratives on the long term. Under the strict control of the Romanian Communist Party, the Romanian society was torn apart by the communist ideology and its criminal mechanisms, including the use of the Romanian Secret Police, the Securitate. These long years of abuse and terror left deep scars on the Romanian history and created complex narratives of the past. Previous studies have identified some major approaches used by the Romanian post-communist society in dealing with the burden of the communist past. The first decade after the 1989 events, which culminated with the end of Nicolae Ceauşescu's regime, was a socially and politically tormented period. The intellectual figures' openness to democracy and their declared separation from the dictatorial past directly contrasted with the former regime grip of power. The recollection of the past in publications and testimonials indicates a specific focus on the topics of communist prisons experiences, forced collectivization, anti-communist resistance and deportation; topics associated with the first decades of the communist regime terror. The public discussions and arguments in this specific area have sustained the trauma memory discourse and have determined its features, as well as the primacy of the victims - perpetrators memory discourse dichotomy. The traumatic memory discourse was closely correlated with the impressive number of testimonies and autobiographical writings focused on past abuses, followed by the open access to the communist regime archives and the public condemnation of communist crimes 5 . Its frame was further enlarged by the inclusion of more diverse and nuanced narratives and counter-narratives, resulted from the autobiographical publications that took some distance from trauma discourse, the literary exploration of everyday life under the Romanian communist regime, and also from the comprehensive research and audio-visual cultural productions focused on the communist past remembrance ${ }^{6}$. Therefore, the trauma approach that dominated the first twenty years following the 1989 regime change was surpassed by means of a deeper involvement

5 More information in Petrescu, Cristina, Petrescu, Dragoș: “The canon of remembering Romanian communism: from autobiographical recollections to collective representations" in Maria Todorova, Augusta Dimou, Stefan Troebst (eds): Remembering Communism: Private and Public Recollections of Lived Experience in Southeast Europe, Budapest, Central European University Press, 2014, pp. 43-70.

6 See for example, Andreescu, Florentina: From Communism to Capitalism. Nation and State in Romanian Cultural Production, New York, Palgrave Macmillan, 2013; Pohrib, Codruța Alina: "The Romanian "Latchkey Generation" writes back: Memory genres of post-communism on Facebook", Memory Studies, 12.2, (2019), pp. 164-183; Preda, Caterina: Art and Politics Under Modern Dictatorships: A Comparison of Chile and Romania, New York, Palgrave Macmillan, 2017; Pușcă, Anca: "Re-Thinking (Post)Communism after The Aesthetic Turn: Art and Politics in The Romanian Context", Millennium: Journal of International Studies, 45.2, (2017), pp. 233-240; Luca, Ioana: "Secret Police Files. Tangled Life Narratives: The 1.5 Generation of Communist Surveillance", Biography, 38.3, (Summer 2015), pp. 363-394; Georgescu, Diana: "Between Trauma and Nostalgia. 
of various agents of memory in the process of coming to terms with the past and by the diverse public memory space taken up by alternative narratives and life stories. Consequently, a polyphonic narrative of the past that enables the coexistence of different narratives and multiple agents of memory was slowly grounded.

Studies of everyday life are considered to offer "more nuanced portraits of the socialist bloc", including data about ordinary activities such as grocery shopping, cooking, leisure and hobbies, as well as about the inter-human relations during the communist regime". The everyday life was largely analyzed as a "constantly evolving phenomenon" - resulting from the interaction established between "political decisions and the responses of ordinary citizens" - and also as "a fundamental site of ideological interventions"9. The common activities carried out in everyday life during Soviet times, such as grocery shopping or leisure activities, were scrutinized as an implicit negotiation that involved the citizens' response to the political regime constraints and limitations, as well as an area deeply influenced by the regime's ideology. The consumption was analyzed in connection with topics such as shortages and struggles to provide the daily goods, but also in relation to pleasure during communism - indulgence and enjoyment, leisure and luxury - even if the activities and goods associated with pleasure were more common to the nomenklatura and the privileged ruling elite. The main frame resulted from the survey of the everyday life under communism mainly highlights the culture of shortages and the socialist regimes "dictatorship" with regard to people's needs ${ }^{10}$. Various studies carry this discussion even further by identifying the background and providing an overview of the leisure and pleasures topics ${ }^{11}$, as well as by dealing with the changes imposed by the Soviet regimes ideology on the borderline between the private and the public areas of life ${ }^{12}$. The research of the everyday life-based accounts provides new perspectives upon the Romanian communist world from various approaches: the regretful perspective of the older generations, adults remembering their childhood under communism, the struggles, regrets and journeys of those who left the country, and, although scarce on the Romanian literary scene, women's memories of their past lives. At the same

The Intellectual Ethos and Generational Dynamics of Memory in Postsocialist Romania”, Südosteuropa, 64.3, (2016), pp. 284-306.

7 Massino, Jill, Penn, Shana: "Introduction. Gender Politics and Everyday Life in State Socialist Eastern and Central Europe", in Massino, Jill, Shana Penn (eds): Gender Politics and Everyday Life in State Socialist Eastern and Central Europe, New York, Palgrave Macmillan, 2009, pp 1-10, here p. 4.

8 Zakharova, Larissa: "Everyday Life under Communism: Practices and Objects", Annales HSS, special issue: Everyday life under communism, 68.2, (2013), pp. 207-217, here p. 211.

9 Crowley, David, Reid, Susan E. (eds): Socialist Spaces. Sites of Everyday Life in the Eastern Bloc, Oxford, New York, Berg, 2002.

10 Kornai, János: Economics of Shortage. Amsterdam, North Holland Press, 1980; Fehér, Ferenc, Heller, Ágnes, Márkus, György: Dictatorship over Needs, New York, St. Martin's Press, 1983; Osokina, Elena: Our Daily Bread: Socialist Distribution and the Art of Survival in Stalin's Russia, 1927-1941, New York, Sharpe, 2001; Hessler, Julie: A Social History of Soviet Trade: Trade Policy, Retail Practices, and Consumption, 1917-1953, Princeton, Princeton University Press, 2004; Luthar, Breda: "Remembering Socialism: On Desire, Consumption and Surveillance", Journal of Consumer Culture, 6.2, (2006), pp. 229-259.

11 Crowley, David, Reid, Susan E. (eds): Style and Socialism: Modernity and Material Culture in Postwar Eastern Europe, Oxford, Berg, 2000; Crowley, David, Reid, Susan E. (eds): Socialist Spaces. Sites of Everyday Life in the Eastern Bloc, Oxford, New York: Berg, 2002); Crowley, David, Reid, Susan E.: "Introduction: Pleasures in Socialism?" in Crowley, David, Susan E. Reid (eds): Pleasures in Socialism: Leisure and Luxury in the Eastern Bloc, Evanston, Illinois, Northwestern University Press, 2010, pp. 3-51.

12 Boym, Svetlana: Common Places. Mythologies of Everyday Life in Russia, Cambridge, Massachusetts and London, England, Harvard University Press, 1994. 
time, the survey of the Romanian life writings dealing with the communist daily life depicts the deep influence of the communist regime over everyday life experiences and the mechanisms used by individuals to evade the regime control. ${ }^{13}$

As a topic, nostalgia is often associated with the exploration of the past through the lens of everyday life and in some cases "the nostalgic fetishization of the notso-distant past" 14 . As Anna Louyest and Graham H. Roberts remarked, nostalgia was a private affair, yet paradoxically, in the former Union of Soviet Socialist Republics (USSR) and former communist Eastern European countries area, where communist regimes caused so much suffering, it became a public, collective one ${ }^{15}$. Collective volumes dedicated to nostalgia in the former communist states include detailed analyses of specific phenomena or personal narratives on a defined top$\mathrm{ic}^{16}$. Maria Todorova describes the media coverage of nostalgia "as a malady" and identifies common sources of nostalgic attitudes in the former Eastern European communist states, including a "merging of economic and social status after the transition", former inclusion in the working class, "pride in production," security and stability, and the ambivalence of attitudes towards the communist past $\mathrm{t}^{17}$. The author emphasizes the desire of those who lived the communist realities to invest their past lives with meaning and dignity. Hence, the people's refuse to accept the status of losers or "slaves" and to project a retroactive agency over their past lives and activities.

In her analysis of the online media related to post-communist nostalgia in Romania, Cristina Petrescu argues that the phenomenon is "neither a desire to restore the past (...) nor an unhealthy denial of the communist crimes. It is a lament for the loss perceived by the individuals who have faced the transition" ${ }^{18}$. The nostalgic point of view was adopted especially during the transition from communism to democracy, when the average Romanians were confronted with a high level of social and

13 See also Massino, Jill: "From Black Caviar to Blackouts. Gender, Consumption, and Lifestyle in Ceausescu's Romania" in Bren, Paulina, Mary Neuburger (eds): Communism Unwrapped. Consumption in Cold War Eastern Europe, Oxford: Oxford University Press, 2012, pp. 226-249; Massino, Jill: Something Old, Something New. Marital Roles and Relations in State Socialist Romania”, Journal of Women's History, 22.1, (2010), pp. 34-60.

14 Bren, Paulina, Neuburger, Mary: "Introduction" in Bren, Paulina, Mary Neuburger (eds): Communism Unwrapped Consumption in Cold War Eastern Europe, Oxford and New York, Oxford University Press, 2012, pp. 3-26, here p. 3.

15 Louyest, Anna, Roberts, Graham H.: “Guest Editors' Introduction: Nostalgia, Culture and Identity in Central and Eastern Europe", Canadian Slavonic Papers, 57.3-4, (2015), pp. 175-179, here p. 175. See also Mihelj, Sabina: "Memory, Post-Socialism and the Media: Nostalgia and Beyond", European Journal of Cultural Studies, 20.3, (2017), pp. 235-251

16 See for example, Todorova, Maria, Dimou, Augusta, Troebst, Stefan (eds): Remembering Communism. Private and Public Recollections of Lived Experience in Southeast Europe, Budapest, Central European University, 2014; Todorova, Maria, Gille, Zsuzsa (eds): Post-Communist Nostalgia, New York, Oxford, Berghahn Books, 2010. For the Romanian context special attention should be paid to the chapters signed by Smaranda Vultur (food and eating habits, daily life and surveillance), Simina Bădică (taking pictures during the communist regime), Andi Mihalache (a chapter about the "'bibelot", "the accessories in our houses"), Cătălina Mihalache (about school, childhood and the communist regime), Corina Cimpoieru (everyday life in an industrial city).

17 Todorova, Maria: "Introduction. From Utopia to Propaganda and Back" in Todorova, Maria, Zsuzsa Gille (eds): Post-Communist Nostalgia, New York, Oxford, Berghahn Books, 2010, pp. 1-16.

18 Petrescu, Cristina: "Nostalgia, Identity and Self-Irony in Remembering Communism", in Stan, Lavinia, Lucian Turcescu: Justice, Memory and Redress in Romania: New Insights, Cambridge Scholar Publishing, 2017, pp. 192-213, here p. 193. 
economic instability, and nostalgia represented a desire to protect oneself from the present $^{19}$.

\section{Late communism and generational discourse}

Research on the everyday life is directly connected to the recognition of the polyphonic nature of remembrance. Different discourses of memory were adopted in the Eastern European post-socialist countries ranging from the denial of socialism, a moderate preservation of the continuity with the socialist past, or even a consolidation of the national identity on the socialist past. ${ }^{20}$ Kirsti Jõesalu provides a compelling analysis of the memory discourse in the Baltic States, using data from Estonia, showing the differences between the official or institutional accounts and other levels of remembering. The socialist period is described, at the public memory discourse level, as a time of "discontinuity", although the biographical accounts reveal a clear preference for the life narrative continuity ${ }^{21}$. Grounding my research on these observations, I refer to the Romanian autobiographical literature in order to overview the conflicting memory discourses in textual self-narratives. I pay special attention to the late communism memory based on its features and its specificity. Following the observed tension between the personal experiences and the public frames of memory, I examine the way in which the self-narration relates to the public memory discourse. The interconnected levels of personal and public memory are recognized, as a narrative is not constructed in isolation, but it involves common narratives and frames of remembrance ${ }^{22}$.

Late socialism is defined in the space of the former Soviet Union as a post-Stalinist period of time spanning for approximately thirty years, between the mid-1950s and the mid-1980s; it has specific features mainly determined by "the performative shift of authoritative discourse and the subsequent normalization of that discourse"23. Referring to the demographic aspects, Alexei Yurchak defines the late socialism generation as "generation-people who were born between the 1950s and early 1970s and came of age between the 1970s and the mid-1980s"24. I adopt Yurchak's expression of generation-people to define the Romanian youth' recounts of the late communist past in autobiographical writings. As specific to the Romanian memory discourse case I prefer to use the phrase "late communism" rather than "late socialism" and to limit this period to Nicolae Ceaușescu's reign of power (mid '60s until the late' 80 s). Some major features of this period include the initial openness to the Western world, the increasing cult of personality of the Communist Party leader, the misery of the

19 Popescu-Sandu, Oana: “'Let’s All Freeze Up Until 2100 or So'. Nostalgic Directions in Post-Communist Romania" in Todorova, Maria, Zsuzsa Gille (eds): Post-Communist Nostalgia, New York \& Oxford, Berghahn Books, 2010, pp. 112-125, here p. 114.

20 Jõesalu, Kirsti: "The meaning of "late socialism": analyzing Estonians' post-communist memory culture", Asia Europe Journal, 8.3, (2010), pp. 293-303, here p. 296.

21 Jõesalu, Kirsti: "The meaning of "late socialism"..., p. 298.

22 See Olick, Jeffrey K.: The politics of regret. On collective memory and historical responsibility, Routledge, New York, 2007; Wertsch, James V.: Voices of collective remembering, Cambridge, Cambridge University Press, 2002.

23 Yurchak, Alexei: Everything Was Forever, Until It Was No More: The Last Soviet Generation Princeton and Oxford, Princeton University Press, 2005, p. 31.

24 Yurchak, Alexei: Everything Was Forever, Until ..., p. 31. 
' 80 s, and also the control exercised by the secret police, the Securitate, and the mistrust instilled within the society. For a short period of time, after Nicolae Ceauşescu came to power and loosened the drastic rules imposed by Gheorghe-Gheorghiu Dej's regime, the citizens' standard of living improved in two main directions. The forced arrests and the subsequent torture of those imprisoned decreased, along with the legal punishments for those who opposed the regime - in direct relation with the decreasing number of the representatives of the former pre-communist elite and regime opponents. Secondly, following the state policy for consumption adopted at the time, Romanian people had better access to consumer goods. However, the Romanian economic distance from the Soviet power and the 1980 European Economic Community's refuse to renew its trade partnership with the Romanian regime, along with Ceauşescu's increasing cult of personality and nationalism, determined the latter to blindly impose his idea to pay off the foreign debt, without fully acknowledging the consequences for the Romanian citizens. Consequently, the export of the majority of Romanian material goods, from gasoline to food products, was followed by the starvation of the average Romanians and social misery ${ }^{25}$.

Yurchak is impressed by the usage of the binary categories to describe the Soviet reality - "oppression and resistance, repression and freedom, the state and the people, official economy and second economy, official culture and counterculture" - and by the description of the Soviet citizens as having no agency in terms of complying with the "communist values"26. The binary categories are also used in analyzing the Romanian communist period, even if the research literature does not yet include significant studies about the citizens' subscription to the communist values based on their personal convictions such as in Yurchak's observations. The literature that addresses the Romanian communist society and the communist system uses especially terms like "duplicity"27, indicating common people's tactics of adaptation, avoiding, or attempting to deceive the regime control. The youth's rebellious nature and the inventiveness in surpassing the imposed rules and regulations are part of the everyday life practices and interactions with the communist regime. Alongside, further research is required with regard to the retroactive nostalgia generated at the generational memory discourse level and its close connection with the past objects and common goods.

Analyzing the generational discourse involving the late communist memories, Kirsti Jõesalu indicates the '70s and ' 80 s generations' contribution to the meaning of the late socialism based on cultural texts and by using on-line media. The generational discourse is defined according to the differences recognized as implicit when taking into consideration the older generations, as well as the Western European contemporaries. The nostalgia gained space in the memory discourse through its association with the late communism specific commodities and leisure practices. Jõesalu identifies nostalgia as a distinguishable marker of these generations' discourse of memory as they seek common references:

"to identify (...) through common textual experience derived from their childhood (cartoons, books, etc.). (...) Besides a common 'textual' experience, they take cognizance of the deficit, the absence of many commodities, inherent in Soviet

\footnotetext{
Massino, Jill: "From Black Caviar to Blackouts..., pp. 226-249.

Yurchak, Alexei: Everything Was Forever, Until ..., p. 5.

27 Kligman, Gail: The Politics of Duplicity. Controlling the Reproduction in Ceausescu's Romania, Berkeley, Los Angeles, New York, The California University Press, 1998.
} 
life in general. (...) They are taking their own nostalgia for their Soviet childhood (describing themselves as a Soviet cartoons generation) as a legitimized nostalgia and opposing it to the nostalgia of older generations, and of the 'nomenklatura'. This confrontation between different generations could be read also from the life stories. ${ }^{28}$

Diana Georgescu notes that whereas the first post-communist decade memorial wave offered "a unified national vision of the communist past", the last decade "exposed its limits, recovering memories divided along generational, gender, ethnic, or class lines" 29 and the recollections of childhood and youth consolidated their position at the level of public memory discourse. Based on the association identified between the producers of these life writings focused on the childhood and youth in Romania communism, Georgescu uses the phrase "generational commonality" to define the generational literary attempt to create a collective identity around common elements specific to everyday life in communism: "Because most projects emerged in informal circles of intellectual friends and appeared in collective volumes, they also facilitated the articulation of a sense of generational commonality." " Alina Codruţa Pohrib pays special attention to the generational memory in Romania in her studies dedicated to the generationalities and material memories of communism and to the reconfigurations of generational identity. Pohrib analyses the "generational, material memories of communism" related to "the 1970s - 1980s generational discourse", and she identifies in the Romanian online sphere the "generational attachment" to communist things ${ }^{31}$ that sustains the generational identity. Pohrib considers that in this case the generationality is closely connected and even defined by the knowledge of material culture:

"the online mnemonic and curatorial practices reveal a different form of identity construction - one which foregrounds generational identity as extricated from traumatic remembering and directly connected to the many objects that are photographed and archived online in clear categories." 32

The online practices ${ }^{33}$ reveal the identity significance given to the "communist memorabilia" "34: toys, products labels, textbooks, clothing items - they generate common memories and sustain the generational identity construction. This "politics of ordinariness" is seen as counterbalancing the dominant narratives of trauma. It also challenges the nostalgic approach of the past by dissociating between different generations' feelings of nostalgia. The objects "act as go-betweens facilitating an implicit dialogue between different generations": those who produce and those who consume them ${ }^{35}$, those who were nostalgic about their active social involvement and

\footnotetext{
Jõesalu, Kirsti: “The meaning of "late socialism”..., pp. 300-301.

Georgescu, Diana: "Between Trauma and Nostalgia..., p. 291.

Georgescu, Diana: "Between Trauma and Nostalgia..., p. 291.

Pohrib, Codruţa Alina: "The afterlives of communist things: Archiving feeling in post-communist Romania", European Journal of Cultural Studies, 19.6, (2016), pp. 724-743, here p. 726.

32 Pohrib, Codruţa Alina: "The afterlives of communist things..., p. 731.

33 See also Petrescu, Cristina: "Websites of memory: in search of the forgotten past", in Todorova, Maria, Augusta Dimou, Stefan Troebst (eds): Remembering Communism: Private and Public Recollections of Lived Experience in Southeast Europe. Budapest, CEU Press, 2014, pp. 747-771.

34 Pohrib, Codruţa Alina: "The afterlives of communist things..., p. 725.

35 Pohrib, Codruța Alina: "The afterlives of communist things..., p. 738.
} 
those for whom different items arouse their childhood or youth memories - "apolitical generatiographical nostalgia" 36 . The generational discourse is defined in this case through the identity construction around the knowledge of the material culture and through the dissociation from the older generation's nostalgia for communism.

\section{Youth in the late communism}

Youth, besides childhood, represented a significant age category prioritized by the former East European socialist regimes through the adopted ideology of creating the new communist society. The educational system was the main instrument used in modeling the young minds, in instilling the communist practices and values and in promoting the subsequent obedience. ${ }^{37}$ The socialist ideology content was included at the level of scientific knowledge taught in schools and universities and it was also part of an extended propaganda that included extracurricular activities through socialist organizations such as the Pioneer Organization, the Union of Communist Youth, or the Union of Communist Students. The Union of Communist Youth (UCY) was founded in 1949 following the Soviet youth communist organization model, the Komsomol. The students were enrolled in order to learn the party culture; the ideological education was made by teachers during high school years. The activities ranged from weekly or biweekly meetings for ideological education, special meetings focussed on the criticism of the incorrect behaviors, demonstrations organized to show support for the Romanian Communist Party and its leader, patriotic and artistic competitions, and even organized trips and camps.

The studies published so far reveal the duplicity resulting from a coercive educational system: the students were forced to participate in different common actions and to behave according to imposed rules $^{38}$, while searching escape routes at the same time. For instance, the chapter written by Ioana Luca in collaboration with Helga Lenart-Cheng for the 2018 collective volume Childhood and Schooling in (Post) Socialist Societies. Memories of Everyday Life reveals the duality of the education received during the communist regime: one the one hand, the influence of the socialist system through children and youth organizations and through imposed gatherings and events aiming at enslaving the pupils' minds by their long rituals and the mantra of the "Golden Age", on the other hand, the "extracurricular activities": family gatherings, play and games, handmade gifts, international literature, all of these creating a mini-world that somehow surpassed the limits imposed by the socialist regime.

A significant direction of research discusses the agency in the former socialist states. Besides the exploring of the opposition and the avoidance tactics practiced when facing the communist educational system, some researchers read the imposed collective activities practiced by the socialist educational system as viable options

36 See Pohrib, Codruţa Alina: "The Romanian "Latchkey Generation” writes back: Memory genres of post-communism on Facebook", Memory Studies, 12.2, (2019), pp. 164-183.

37 For more information about socialist ideology and youth policies, see Yurchak, Alexei: Everything Was Forever, Until ..., and Fürst, Juliane: Stalin's Last Generation. Soviet Post-War Youth and the Emergence of Mature Socialism, Oxford, Oxford University Press, 2010.

38 See also Saunders, Anna: Honecker's Children: Youth and Patriotism in East(ern) Germany, 1979-2002, Manchester, Manchester University Press, 2007; Taylor, Karin: Let's Twist Again: Youth and Leisure in Socialist Bulgaria, Münster, LIT Verlag, 2006. 
for self-fulfillment through direct engagement with state structures ${ }^{39}$ For example, Diana Georgescu provides an extensive analysis of the team expeditions organized in Romania which were promoted by the educational organizations during communism. She argues against the oppositional terms representations of the relationship between citizens and the late socialist state and she asserts the engagement of the citizens with the organizational structure based on the internal association with the socialist values promoted by the communist regime. Georgescu's approach is inscribed in the research trend arguing for recognizing the citizens' agency in the former socialist states ${ }^{40}$. Therefore, she departs from the research literature focused on the homogenizing and disciplining aspects of socialist education and she argues that through the performative character of the actions involved "various forms of youth agency were built into the socialist pedagogy of citizenship, which encouraged activism, voluntarism, leadership, and scientific positivism in youth". ${ }^{41}$ The main assumption in this case is that the performance itself, even if inscribed in the organizational frames, involves unpredictability and therefore it allows individual agency: "opening the ambiguous socialist ideology to acts of appropriation and resignification" 42 .

Veronica Szabo argues that the ideological indoctrination of youth during the 1980s was more an intention than an outcome and that during the last decade of the communist regime in Romania the ideological education through formal education and youth organizations was undermined within the family space. ${ }^{43}$ Adrian Solomon contests the extensive manipulation assumed to be made by the communist regime through the educational system: "If one is still wondering whether those who grew up under Communism were brainwashed, the best answer, perhaps, is the 1989 anti-Communist revolution: most of those who took to the streets, risking their lives, had spent their middle childhood during its heyday." ${ }^{4}$

As shown above, the analysis of youth's everyday life during late communism departs from the paradigm of totalitarianism, even if initially the youth organizations exercised significant pressure and were designed by the Communist Party as instruments of propaganda and control. The analysis of the ideological education targeting children and youth must be very carefully framed in the social and political context that seemed to have variable features corresponding to different periods of time. The

39 Georgescu, Diana: "Small Comrades as Historians and Ethnographers: Performativity, Agency, and the Socialist Pedagogy of Citizenship in Ceaușescu's Romania, 1969-1989”, Slavic Review, 78.1 (Spring 2019), pp. 74-102.

40 See for example the debate between Nanette Funk and Kristen Ghodsee points to the complexity of acknowledging the women's general or partial agency during the communist regimes. Funk, Nanette: “A very tangled knot: Official state socialist women's organizations, women's agency and feminism in Eastern European state socialism”, European Journal of Women's Studies, 21.4, (2014), pp. 344-360; Funk, Nanette: “(K)not so: A response to Kristen Ghodsee”, European Journal of Women's Studies, 22.3, (2015), pp. 350-355; Ghodsee, Kristen: "Untangling the knot: A response to Nanette Funk," European Journal of Women's Studies, 22.2, (2015), pp. 248-252.

41 Georgescu, Diana: "Small Comrades as Historians and Ethnographers: Performativity, Agency, and the Socialist Pedagogy of Citizenship in Ceaușescu’s Romania, 1969-1989”, Slavic Review, 78.1, (Spring 2019), pp. 74-102, here 77 .

42 Georgescu, Diana: "Small Comrades as Historians ..., p. 78.

43 Szabo, Veronica: Youth and Politics in Communist Romania (1980-1989), PhD thesis, University of Pittsburgh, 2012 .

44 Solomon, Adrian: "Buffeted by Political Winds Children's Literature in Communist Romania", Boyhood Studies, 10.2, (Autumn 2017), pp. 118-139, p. 135. 
communist propaganda itself suffered various modifications ${ }^{45}$ during the late communism and the effects were visible at the educational level. The debate around the agency as the individuals' potential to act using various strategies to elude the regime control or as appropriation and resignification of the communist practices and values remains open. The autobiographical writings can offer significant data to sustain the previous findings.

\section{Post-transitional autobiographical literature}

A major segment of the literature exploring the memories of the late communism in direct relation with the everyday life practices is represented by the collective volumes published after 2000 whose general aim was to gather the personal memories and experiences of the past. For example, Cartea roz a comunismului (The pink book of communism) (2004), edited by Gabriel H. Decuble, was one of the first volumes dedicated to the everyday life memories. ${ }^{46}$ Out of 14 chapters, four belong to wellknown women public figures, their narratives being centered on the topics of childhood and education during communism (pupils and teachers). In 2006 Călin-Andrei Mihăilescu edited another volume detailing the daily reality of the communist past. ${ }^{47}$ It includes 27 stories written by well-known public personalities (writers, political analysts, etc.). The volume presents fragments from the experiences of Romanian intellectuals, including testimonials of those who were professionally active under the communist regime or managed to emigrate, combining past memories of specific events or daily life details with literary forms of expression. Besides depicting the intellectuals' lives and struggles under the communist regime, the volume also explores the regime's influence on various aspects of daily life. A series of collective volumes were edited by Dan Lungu and his collaborators. One of the leading life writings focused collective volume in exploring the women's narratives - and from many points of view the only one dedicated to the women's everyday life experiences during the communist regime, Tovaraşe de drum. Experienţe feminine in comunism (Road comrades. Feminine Experience in Communism) (2008), edited by Radu Pavel Gheo and Dan Lungu, is presented by the editors as the result of the public attention shift from the history of intellectuals and their lives during the Romanian communist regime to that of common people's lives and histories. ${ }^{48}$ The contributors belong to different age groups and they are highly educated intellectuals who share the same cultural background. Using the framework of the everyday life experience and women's self-writing, the volume is centered on four main topics: everyday life shortages, sexual relations and the implicit abortion, the reality of women's social and living conditions, and immigration followed by "adjustment" to the new country. The volume Cărţi, filme, muzici şi alte distracţii din comunism (Books, Movies, Music and other Distractions under Communism), edited by Dan Lungu and Amelia

45 See Preutu, Cristina: Propagandă politică în România socialistă: practici instituţionale şi tehnici de comunicare:(1965-1974) (Political Propaganda in the Socialist Romania: Institutional Practices and Communication Techniques), Iași, Editura Universității Alexandru Ioan Cuza din Iași, 2017.

46 Decuble, Gabriel H. (ed.): Cartea roz a comunismului, n.p., Editura Versus, 2004.

47 Mihăilescu, Călin-Andrei (ed.): Cum era? Cam aşa: Amintiri din anii comunismului (românesc), Bucureşti, Curtea Veche, 2006.

48 Gheo, Radu Pavel, Lungu, Dan (eds): Tovarășe de drum. Experienţe feminine în comunism, Iași, Polirom, 2008. 
Gheorghiţă in 2014, includes memories of the past related to cultural consumption and associated social practices during the communist period. ${ }^{49}$ The volume includes more than thirty contributions from people with different backgrounds, and while the call for papers for this volume was circulated on a Facebook page, other contributions were requested directly; some of the contributors can be easily located chronologically during the late communism. The everyday life practices were also explored in the volume Cartea copilăriilor (The Book of Childhoods) (2016), a collection of memories related to childhood that includes over sixty essays written by both wellknown writers and ordinary people. ${ }^{50}$ The editors made a public appeal for contributions related to childhood memories, including remembrances of toys and games, places and special events, holidays, travel and summer camps, music and books, and family relationships. Similarly, the volume Și eu am trăit în comunism (I lived under communism, too), edited by Ioan Pârvulescu, includes stories of the past related to daily life experiences. ${ }^{51} \mathrm{~A}$ wide range of testimonies, gathered from more than one hundred people of various ages across a variety of professions is included in the volume. The editor combined the testimonies of highly educated people, including well-known writers, researchers, doctors, actors, and journalists while demarcating the contributors to address twenty topics, including urban life, travel, food, clothes, education, and various shortages.

Besides the edited volumes another category of publication is represented by the collaborative volumes, written by two or more authors and following the personal memories of shared communist past. For example, the volume O lume dispărută (The Lost World. Four Personal Histories) (2004), weaves together the childhood and youth memories of four Romanian writers - Paul Cernat, Ion Manolescu, Angelo Mitchievici, and Ioan Stanomir - and cultivates the "generational commonalities" 52 . The volume R'Estul şi Vestul (The R'E(a)st and the West) is written by Mihaela Miroiu in collaboration with Mircea Miclea in 2005 and offers valuable insights in the communist everyday life experiences. It represents a self-reference work, written as a dialogue between two very close friends who in an exchange of emails mutually challenge their memories of the communist past, their thoughts over the transitional period, questioning the way their self-development was marked by their past. Their friendship provides the background for the open dialogue that further allows a close reading and questioning of the other memories and self-presentation - "we are of different ages and have different perceptions as "witnesses" enhancing the entire process of remembering the past.

Another series of collective volumes addressing the memories of the late communism was published between 2009 and 2013 by the ART publishing house (Prima dată, My first). The series includes the contributors' memories references to the youth's lives in communism, even if this is not the main aim of this collection. In the last volume of the series Andra Matzal writes that the nine volumes published were not simple literature or anthropology, but reconstruction exercises of a history that became common to the contributors through its intimacy archaeology. ${ }^{54}$ The volumes

\footnotetext{
Lungu, Dan, Gheorghiță, Amelia (eds): Cărţi, filme, muzici şi alte distracţii din comunism, Iaşi, Polirom, 2014. Lungu, Dan, Gheorghiță, Amelia (eds): Cartea copilăriilor, Iaşi, Polirom, 2016.

Pârvulescu, Ioana (ed.): Şi eu am trăit în comunism, Bucureşti, Humanitas, 2015.

Georgescu, Diana: "Between Trauma and Nostalgia..., p. 295.

Miroiu, Mihaela, Miclea, Mircea: R'Estul şi Vestul, Iaşi, Polirom, 2005, p. 15.

Albulescu, Laura, Matzal, Andra (eds): Prima dată, Editura Art, București, 2013.
} 
are constructed around specific topics (the first book, travelling abroad, jeans, love disappointment, etc.) and some of the contributions are chronologically and topically interconnected with the memories of the youth years during the late communism.

As the main outcome of this chapter refers to the generation-people's memory of the late communism in Romania, the focus fell on the collective and collaborative volumes targeting everyday life. The analysis of the above-mentioned volumes is performed based on the chronological and topical area they address. In my readings, I focus on the main representations and topics resulted from the narrativization of generational memories. The gender perspective, even if poorly represented at this level, is highlighted in the analyzed autobiographical material by indicating the gender roles and the Romanian communist regime expectations.

\section{Youth memories: narrativization and self-referential writings}

The autobiographical literature reveals a complex narrative of the past, involving the transition as inherent to youth years, along with specific data of the life conditions and challenges during late communism. Two different levels of memories and experiences are explored: the education during the late communism and the commodities and leisure practices, mainly described as "socialist escape" commodities and identified generational memory associated to the late communism, two different approaches are mainly used: one that indicates the everyday life necessities and struggles and another one that focuses on the complex sensorial memories involved by the entire act of acquiring different commodities that became sources of pleasure: movies, books, clothes, etc. This realm of memory indicates both the material deprivation and the intense desire and pleasure resulted from the commodity itself alongside the personal capacity to fulfill the initial desire. Many personal recounts of the late communism indicate the impossibility to clear cut between childhood memories and youth experiences as for many young people the end of communism corresponded to the beginning of their maturity. Following these different approaches of the past experiences and memories, I identified three interconnected topics presented below alongside the discussion of the generated generational memory and agency presence.

\section{a. Self-reflexivity in relation with the communist regime and its practices}

One of the central topics of the self-narratives is the personal relation with the regime practices and the mechanisms to cope with authority and limitations. A high level of elaboration of the narratives of the communist past is directly correlated with the self-referential discourse related to the regime ideology and its practices. The formal education in accordance with the official ideology was a major directive of the communist propaganda. Besides the ideological content included in the curricula, formal education required that all the pupils and students be included in socialist collective activities and practices. The former students remember the daily mantra of their role in constructing the "new society": "We always heard that we

55 Giustino, Cathleen M., Plum, Catherine J., Vari, Alexander: Socialist Escapes: Breaking Away from Ideology and Everyday Routine in Eastern Europe. 1945-1989, Berghahn Books, Oxford and New York, 2013. 
were the foundation of the new superior system to the consolidation of which we had the supreme duty to participate. Each of us, we were told, represented the country's future, the new man". ${ }^{56}$ In some cases, based on specific individual qualities, the students were selected to represent their colleagues and their schools in extracurricular activities dedicated to the Romanian Communist Party and its supreme leader, Nicolae Ceaușescu: official shows, homage contests, physical competitions preceded by intense and time consuming practices, etc. The image of the communist leader, the general secretary of the Romanian Communist Party, Nicolae Ceauşescu, dominated the institutions offices, including schools and universities amphitheaters: "the persistence of a presence" 57 , with great efforts undertaken by the educational system to preserve and increase his cult of personality. Paul Cernat writes that during his school and high-school years he lived with the constant fear of being selected for one of these "glorious" activities. He describes his tactics to avoid these activities and performances and his inner opposition against becoming part of the educational instrument serving Ceaușescu's cult of personality. During each school year, different communist activist teams tried to persuade the young people to volunteer for artistic or sports activities dedicated to the communist party and its leader. Cernat's adopted tactic was that of mediocrity: never to show his abilities in specific required areas. As a self-protection measure he would refrain from using his writing talent, as he believed that to publish anything in an official propaganda magazine would be like expressing his adhesion to the communist regime..$^{58}$

The influence of technological production - highly ranked by the communist ideology, but outdated as far as knowledge and results were concerned - over the educational system is criticized in different recounts of the educational experiences during the late communism: "In 1977, in my third year in high school, the Romanian education knew the assault of the technical disciplines (...) To be an engineer becomes the supreme noblesse title in communism" 59 . Cernat writes about the forced industrialization of high-schools. Ion Manolescu also describes the infusion of technology even at the level of high-schools' human sciences sections and universities' Philological studies. His memories of the late communist past indicate the youth's non-conformist attitude as being directed against the communist system: "the communist system (mediocre, restrictive and indoctrinated) was exactly what we needed to assert ourselves". ${ }^{60}$ The duplicity and the sterile language promoted by the educational system in accordance with the communist ideology found its way even in the literary comments that were used in teaching and were to be exactly reproduced by students in their works. The love for reading was mainly the result of the family education, as the formal education promoted only the ideologically accepted literature. An entire network of relatives and friends was used to access qualitative literary works. Ioan Stanomir writes about the passion for literature as a way of surviving to the formal education. Through lists of ideological readings and educational practic-

\footnotetext{
Pârvulescu, Ioana (ed.): Şi eu am trăit..., p. 56.

Cernat, Paul, Manolescu, Ion, Mitchievici, Angelo, Stanomir, Ioan: O lume, p. 329.

Cernat, Paul, Manolescu, Ion, Mitchievici, Angelo, Stanomir, Ioan: O lume dispărută, Polirom, Iași, 2004, p. 80 .

59 Pârvulescu, Ioana (ed.): Şi eu am trăit..., p. 220.

60 Cernat, Paul, Manolescu, Ion, Mitchievici, Angelo, Stanomir, Ioan: O lume, p. 139.
} 
es, the formal education imposed a suffocating monotony disguised as "emancipation through education" 61 .

The formal education insisted on the gender traditional roles, despite the socially assumed gender equality. In many of her studies, Mihaela Miroiu critically assesses the Romanian communist propaganda of gender equality as being a hollow theoretical and ideological approach to the Romanian women's lives and rights, used solely to the benefit of the regime and its increasing power. ${ }^{62}$ Family planning politics was used in the communist bloc of Eastern Europe as a response to the constant need to increase the workforce in order to achieve the communist ideological goals. Women were thus given another essential role, the duty to procreate; carrying a child turned into a social activity. In Romania, family planning politics had severe repercussions. Personal trauma resulting from the demands made on women eclipsed any benefits intended by the communist regime. The party-state introduced the forced gynecological control both in schools, for teenage girls suspected of not being virgins ${ }^{63}$, and at the workplace. Cernat remembers that during the high-school classes some activists and nurses would visit the classroom in order to speak to the students about sexual education. Besides the students' silence and the nurses' "nonsensical" words, the educational discourse targeted especially the girls: "they advised the girls to become good mothers, to give birth to many children for our socialist country" ${ }^{\text {" }}$. These advices resumed the regime's ideology and the associated gender roles.

\section{b. Educational relations and the communist organizations}

The description of the teachers and professors is seconded in the recounts of the youth's years by the narrative of the material differences between students caused by their families' inclusion in the communist apparatus. The heirs of the nomenklatura had various material privileges and they often had access to high-quality education based only on their privileged status, without demonstrating an adequate intellectual level. The privileged youth's access to Western goods (music and clothes) that were on the top of young people's list of wished frequently included in the autobiographical writings. Alongside the heirs of the nomenklatura, another category of privileged people were those who were recruited from a young age to collaborate with the Securitate and who would receive special benefits as payment for their services.

The organizations in charge of modelling young people in compliance with the communist ideology imposed a series of activities for the entire student population. The meetings and the elections for different key positions mainly concerning the communist propaganda were not only time consuming but they were also used as control mechanism enforcing the mass obedience. The recounts bring forward the uselessness and the absurdity of these practices: "Our generation wasted much of its energy. (...) Someone was giving a speech and was saying a name. We, the students, had to chant the name and to applaud (...) The meetings lasted until midnight and to return home, without public illumination and through desolate streets was

${ }_{61}$ Cernat, Paul, Manolescu, Ion, Mitchievici, Angelo, Stanomir, Ioan: O lume, p. 361.

${ }^{62}$ See for example Miroiu, Mihaela: “'Not the Right Moment!' Women and the Politics of Endless Delay in Romania," Women's History Review, 19.4, (2010), pp. 575-593.

63 See personal memories in Miroiu, Mihaela, Miclea, Mircea: R'Estul și ....

64 Cernat, Paul, Manolescu, Ion, Mitchievici, Angelo, Stanomir, Ioan: O lume, p. 101. 
a real problem." 65 The wasted energy and time are deplored in many narratives of the past. Besides, some authors indicate the inclusion in different communist youth organizations especially in the ' 70 as a form of social engagement and as a form of theoretical separation from their parents' generation. For example, Miroiu recounts the personal inclusion in the Union of Communist Youth in terms of youth's rebellious nature, as a period of time when she and her colleagues distanced themselves from the images of the Soviet past and from the rediscovery of the national identity - specific to their parents' generation - and looked forward towards a brighter future. These young people in "blue jeans and adidas", who listened to the news broadcast by Free Europe and to Western music, disregarded the older generation's ideals and naively embraced - even for a short time - the communist organizations as a viable instrument for defining their identity in relation with the older generation and with the Occidental youth: "I was not embarrassed to be UCY secretary in that world. I coordinated the high-school journal, the literary meetings, the skipping class hours when we preferred to go to the cinema, to concerts or in the park (...) We were, to say so, the sons and the daughters of the larger world that we believed to be part of." 66 On the other hand, the ' 80 s dominated by the struggle to survive and the challenges brought along by the status change - from student to high-school teacher, from teenager to young mother - completely changed Miroiu's perception of the communist world and of the years spent under the communist regime: "every day counted" 67 .

The first professional shocking encounter with the absurdity of the regime was in many cases caused by the process of job recruitment, an area fully controlled by the state. Some of the former students received a supplementary percent at their final exams based on their political activity and consequently they had access to better jobs. Mircea Miclea writes that he saw brilliant former students who were forced to work under their intellectual and professional level and lost forever their chances to thrive and to fulfill their intellectual potential. His direct encounter with the misery of the communist regime begins after he graduates from university and when, as a school teacher, he experiences the devastating social effects of the regime ${ }^{68}$.

Another common element included in the autobiographical writings related to the youth years in the late communism refers to the memories of the "voluntary work", including the compulsory participation in military exercises known as preparations for defending the country. Stanomir recounts the pre-military preparation from highschool, but ironically writes that the only time when the students proudly wore the uniforms where when the entire high-school population was sent as "an authentic expeditionary corpus" to sort the potatoes 69 . The forced work - "voluntary work" - was in fact a period of time in which formal education was replaced by agricultural work. The students were transported to different regions where additional work force was needed. They lived in unsanitary conditions, they were very poorly fed and worked all day to fulfill a personal quota: sorting potatoes, collecting fruit and vegetables, etc. More than often, they returned home after some weeks in very poor health. In some cases, the students were sent to "voluntary work" on the construction sites, even if they had no knowledge in the field. One former student from the Faculty of

65 Pârvulescu, Ioana (ed.): Şi eu am trăit..., pp. 228-229.

${ }_{66}$ Miroiu, Mihaela, Miclea, Mircea: R'Estul şi ..., pp. 44-45.

67 Miroiu, Mihaela, Miclea, Mircea: R'Estul și ..., p. 24.

68 Miroiu, Mihaela, Miclea, Mircea: R'Estul şi ..., p. 114.

69 Cernat, Paul, Manolescu, Ion, Mitchievici, Angelo, Stanomir, Ioan: O lume, p. 371. 
Chemistry remembers her role in the construction of the Bucharest Opera: "It was clear that (...) they did not need our work (...) and they would just ask us to move some planks from one place to another. During the next week (...) we were told to move them back to their initial place" ${ }^{70}$. For Miroiu the memories of the forced agricultural "voluntary work" reveal the social misery, the mental degradation and the loss of any interest in self-development and cognitive progress when confronted with the work routine in deployable conditions: "In the first two weeks we'd still have conversations about the specialty subjects, as we took with us books to read for our final exam. After that we cracked and adapted. (...) speaking more and more laconically, on subjects that were adjusted to the context: if they would take us to gather beet, if the trucks bringing our lunch would come to the field on time (...)." Her forced agricultural experiences continued in her years as a high-school teacher, when she worked alongside her students. Her only hope and salvation remained her knowledge and mind: "All that I could humanize was the atmosphere. I used to make them [the students] discuss drama, novels, philosophy, music. I was afraid that they would start to resemble the potatoes they were sorting" "72. Through non-formal education and personal involvement some teachers and professors tried to make a clear distinction between their identity and the communist system in which they worked.

\section{c. Commodities and pleasures - communist memorabilia and nostalgia}

Cernat writes that almost every product from Ceaușescu's era was commonly scrutinized using the question: Is it good or is it made in Romania? ${ }^{73}$ And the strict evaluation concerned a wide range of items: from food, drinks, and sweets to clothes and home products. Even if all the family members participated when necessary, the well-known efforts for daily goods supplies were mainly the adults' tasks. Facing the lack of basic products, the personal inventiveness became a supplying tool and also a source of difference. For example, the young people did all that was possible to stand out from the grey palette that dominated the Romanian clothes production. Stanomir indicates the youth's appreciation for the Western products and their evaluation of the local products: "to each of the capitalist products corresponds a replacement that was easy to identify through its odorless and insipid nature" ${ }^{\text {" }}$. A good range of memories related to the commodities in the late communism and the associated practices are included in Books, movies, music, a volume that focuses on the cultural consumption during communism. The recounts navigate around the efforts and the satisfactions of accessing the desired goods, especially movies and music.

Indisputably, the most desired object from the late communist was a pair of American blue jeans and even if the copies were reluctantly accepted, they were never associated with the same desire and they did not represent the same powerful identity mark. Cătălin Avramescu writes that "the trouble was that (...) the pants from the South of the Danube did not resemble the American jeans. Obviously, this made them a bastard-product. They did not play their destined role, that of the line that separates two social categories. One who dressed up with this copy pants had a

\footnotetext{
Pârvulescu, Ioana (ed.): Şi eu am trăit..., p. 55.

Miroiu, Mihaela, Miclea, Mircea: R'Estul şi ..., p. 110.

Miroiu, Mihaela, Miclea, Mircea: R'Estul și ..., p. 111

Cernat, Paul, Manolescu, Ion, Mitchievici, Angelo, Stanomir, Ioan: O lume, p. 113.

Cernat, Paul, Manolescu, Ion, Mitchievici, Angelo, Stanomir, Ioan: O lume, p. 348.
} 
hybrid identity. He/she swayed between two cultural worlds, hanging from uncertain vine" 75 . The blue jeans were not a simple object, they had the power to indicate the social category, as the access to foreign goods was mainly an advantage of the party nomenklatura and in some cases of those who had relatives who emigrated and were able to send packages. Mircea Cărtărescu also indicates the power of the blue jeans, defined back then as "capitalist and immoral pants" ", to differentiate between the privileged ones and the rest of the world.

An entire network supported the black market in Eastern Europe with products ranging from jeans and cigarettes to electronic products. ${ }^{77}$ If the official position incriminated the Western goods, the youth's appreciation left significant marks at the memory level. The recounts contain details almost impossible to believe regarding the jeans' texture, color, design of the label, their zippers and their sounds ${ }^{78}$. The narratives indicate that besides the jeans, defined by Virgil Mihaiu as a sort of counter-uniform to that imposed by the communist regime, other goods, such as the video player, the Western music and the movies obtained on the black market, represented more than simple commodities; they were part of the youth's subversive and rebellious spirit.

Apart from the highly evaluated and longtime desired Western goods, the generational memory is retroactively constructed around the communist products. The recounts indicate not only the scarcity of living in communism and the everyday life struggles, but also the significant role occupied by these commodities memories at the level of generational discourse. Entire pages are dedicated to the food products and in some cases the self-assessment in relation with the late communism is overshadowed by the material world description. For example, Ion Manolescu in his recounts - "My collection of lost objects and useless memories" - relates his nostalgia with the material world of the communist memorabilia and he dedicates four pages to this material world description, including: fridge, TV, watches, clothes and shoes, soaps, drinks, food, sweets, etc. He writes fondly about his madeleine - "more terrible than any Ceausescu-related reality: a mental box of images from the past, in which the joy and the sorrow mix in equal parts (...) Here parade all the necessary and useless objects of the communist daily life, linked together by the colored ribbons of nostalgia (...)"79. Another background of nostalgia is indicated by Angelo Mitchievici - that of the lost possibilities: the childhood and youth years when in the absence of the communist regime the course of life could prove to be very different ${ }^{80}$.

\section{Conclusion}

The nostalgia and the consequent differences found between different generations are interlinked with the conflicting lines observed at the level of memory discourses. A significant connection between nostalgia and communist memorabilia is identified

\footnotetext{
Bernic, Corina (ed.): Primii mei blugi, Art, București, 2009, p. 16.

Bernic, Corina (ed.): Primii mei blugi, Art, București, 2009, p. 41.

Chelcea, Liviu: "The culture of shortage during state-socialism: consumption practices in a Romanian village in the 1980s," Cultural Studies, 16.1, (2002), pp. 16-43.

78 See Alexandru Dabija's recounts in Bernic, Corina (ed.): Primii mei blugi, Art, București, 2009, pp. 57-62.

79 Cernat, Paul, Manolescu, Ion, Mitchievici, Angelo, Stanomir, Ioan: O lume, pp. 141-142.

80 Cernat, Paul, Manolescu, Ion, Mitchievici, Angelo, Stanomir, Ioan: O lume, pp. 170-171.
} 
in the self-narratives of the late communism youth generation, and in some cases the self-reference is overshadowed by the material world description. The youth's features associated with their inherently rebellious and inventive nature determined different forms of agency as opposition and dissociation from the communist system. The memories of active engagement in procuring desired commodities are closely connected to different manifestations of agency and hint to the complex connection between nostalgia and communist memorabilia. The autobiographical writings indicate that the desired commodities were steadily and closely followed. Through different actions and practices, and despite the regime's interdictions and opposition, the commodities possession became real. Therefore, the communist memorabilia involves not only childhood and youth's memories, but also memories of individual agency in forms of personal actions by means of which the communist system was confronted, opposed or averted. The specific youth's features, including the great adaptability capacity, allowed for different interactions with the communist regime, and consequently the variability of the self-narratives and the conflicting lines between different generations' narratives. The youth's response to the political regime's constraints and limitations, as well as the connection between nostalgia and the communist memorabilia, are part of the generational discourse that significantly departs from both trauma discourse and memories of the everyday life struggles. 